\title{
Beware the Nanny State: Neoliberal Ideology and American Health Law Reform
}

\author{
David Ray Papke \\ Marquette University, Milwaukee, WI, USA \\ Email: david.papke@marquette.edu
}

How to cite this paper: Papke, D. R. (2020). Beware the Nanny State: Neoliberal Ideology and American Health Law Reform. Open Journal of Political Science, 10, 278-301. https://doi.org/10.4236/ojps.2020.102018

Received: December 13, 2019

Accepted: March 28, 2020

Published: March 31, 2020

Copyright ( 2020 by author(s) and Scientific Research Publishing Inc. This work is licensed under the Creative Commons Attribution International License (CC BY 4.0).

http://creativecommons.org/licenses/by/4.0/

\begin{abstract}
This article identifies neoliberalism as an important contemporary ideology and then examines the impact of this ideology and its concomitant rhetoric on public health law in the United States. In particular, the article considers the impact of neoliberalism on laws restricting the size of sugary soft drinks, requiring motorcyclists to wear helmets, and mandating graphic warnings on individual cigarette packages. In each area, neoliberalism helped thwart efforts at law reform, much to the ultimate detriment of the public's health. When these developments are underscored, they bring into higher relief the important relationship of ideology and law.
\end{abstract}

\section{Keywords}

Ideology, Neoliberalism, Motorcycle Helmet, Sugary Soft Drinks, Graphic Warnings on Cigarette Packages

\section{Introduction}

Neoliberalism is an especially noteworthy variety of contemporary ideology. Like other ideologies, it includes a normative vision of socio-political life, one which can be inspiring, influence perceptions, and prompt action. Neoliberalism also employs a rhetoric consisting of highly persuasive images and language. This rhetoric tells us pointedly what we should love and what we should hate. The rhetoric unabashedly lionizes those it takes to be heroes and condemns the villains lurking among us.

To be more specific, neoliberalism calls for a reliance on the market as a social ordering mechanism. Within the marketplace and elsewhere, according to the neoliberal, people are able to make choices and to assert themselves. The ever-expanding and paternalistic government, by contrast, impedes our ability to make choices. If we are not vigilant, this type of government will blithely and 
arrogantly deny our freedom.

In recent decades, neoliberal ideology and its concomitant rhetoric have played important roles in attempts at law reform in the United States. Employed on the local, state, and federal levels, this ideology and rhetoric have proven especially effective in limiting law reform related to the public's health. In particular, this rhetoric has been a major factor in legal debates over the size of sugary soft drinks, helmets for motorcycle riders, and graphic warnings on cigarette packaging. These examples of proposed law reform, along with many others, have been deplored by neoliberals as the work of the villainous "nanny state".

The success of nanny-state rhetoric in thwarting law reform related to the public's health is unfortunate and, with an eye to future political struggles, should be underscored. Part One of this article defines ideology and ideological rhetoric and places neoliberalism into this conceptual framework. Part Two explores the roles neoliberal ideology and rhetoric, especially comments related to the nanny state, have played in law reform debates related to sugary soft drinks, motorcycle helmets, and cigarette packaging. Neoliberalism, of course, is not solely responsible for the defeats of law reform in these areas, but, as a review of the most important case law and legislation will suggest, neoliberalism has contributed to the defeats of major law reform proposals. In Conclusion, I review the major features of neoliberal ideology and rhetoric and underscore their problematic implications regarding contemporary health problems. For purposes for this article, neoliberalism is not so much "right" or "wrong" as it is annoyingly obtuse when it comes to appreciating and addressing the public's health.

\section{Part I: Neoliberal Ideology and Rhetoric}

1) Ideology and Ideological Rhetoric

Commentators have for many years attempted to define, develop, and even dismiss the notion of "ideology". Wringing his hands at the many directions in which discussions of ideology have gone, one important scholar has suggested we think of "ideology" itself as "a text, woven of a whole tissue of conceptual strands..." (Eagleton, 1991: p. 1). I will not attempt to decipher this "text" but rather will utilize a quite general understanding of "ideology" before, in subsequent sections, discussing neoliberalism and its importance in law reform.

For purposes at hand, ideologies consist of assorted principles, ideas, concepts, and propositions that add up to a blueprint for society. Although non-scientific and non-epistemic, ideologies are highly normative. Usually, they tout what they take to be the best economic and political systems. Often, they serve to legitimate the dominant system and its set of power relations, but ideologies might also be oppositional, e.g., a socialist ideology in the midst of a capitalist system (Williams, 1979).

Where do ideologies originate? While political leaders and government officials are especially obvious "ideologues", that is, promoters of given ideologies, various additional individuals, groups, and institutions also produce and develop ideology. The quirky French postmodernist Louis Althusser pointed out in the 
1970s that many ideologues are not active in what we might consider politics. Ideology, Althusser maintained, originates in many places. Not only political parties and government agencies but also schools, publishing houses, and news organizations can be highly ideological (Althusser, 1971). Even holiday celebrations, festivals, and cultural events are sources of ideology (Althusser, 1971).

Unfortunately, Americans are usually limited in recognizing, much less critiquing, ideology of any type. Part of the problem is that even the minority of Americans who discuss ideology tend to understand it chiefly as a falsehood or as a lie about who has power and about what people with power are doing with it (Silbey, 2006). But the label "ideological" need not be pejorative. "[I]deology is no baseless illusion but a solid reality, an active material force which must have enough cognitive content to help organize the practical lives of human beings" (Eagleton, 1991: p. 26). Rather than being false or incorrect, ideology is essentially an aligned, highly normative worldview.

To the extent an ideology comes alive, it is usually not due to the coherence of a given cluster of normative ideas but rather due to its accompanying rhetoric, that is, its particularly fiery attempts to persuade (Condor et al., 2012). The rhetoric for a given ideology will include no shortage of eye-catching images and sloganeering and is likely to rely on hyperbole, irony, and analogy, among other devices (Brockway, 2016). This ideological rhetoric might be expected to pointedly identify what it takes to be copacetic and what it considers disagreeable. It will praise what it thinks is heroic and deplore what it believes is villainous. The latter might be especially important, for as the philosopher Eric Hoffer once observed, "Mass movements can rise and spread without a god, but never without belief in a devil" (Hoffer, 1951: p. 1).

From the time of Aristotle to the present, critics have cast ideological rhetoric as evidence that public discourse, that is, our discussions of goals and policies, has broken down (Thompson, 2016), but we should not underestimate the direction and inspiration that ideological rhetoric might have. Ideology and its rhetorical handmaiden contribute to the acceptance or rejection of government institutions and economic arrangements. They establish, preserve, and alter power relations. They situate a socioeconomic class or a whole nation in a larger context. It is hardly surprising, given this influence and power, that an ideology and its concomitant rhetoric can affect law reform.

2) Neoliberal Ideology and Rhetoric

Neoliberalism is "one of the most powerful ideologies of the twenty-first century" (Giroux, 2008: p. ix). Like the ideologies described generally in the preceding section of this article, neoliberalism proffers a non-scientific but normative set of values and beliefs about government, the economy, and social life in general. In particular, neoliberalism promotes tax cuts for businesses and the well-to-do; financial austerity within government; and deregulation of business enterprises. "Neoliberalism is broadly defined as the extension of competitive markets into all areas of life, including the economy, politics and society" (Springer, Birch, \& MacLeavy, 2016: p. 2). A neoliberal would assert that we should look to 
the private market and rely on it rather than government. Indeed, neoliberals maintain, a smaller, less intrusive government would make it more likely that citizens could maintain and exercise their liberty. According to blogger Michael Snyder:

America has been overrun by control freaks. Once upon a time the United States was considered to be "the land of the free and the home of the brave", but today there are millions of laws, rules, and regulations that tightly regulate our daily lives. Most of these laws, rules, and regulations were established by people who believed that they had "good intentions", but at this point the nanny state has become so oppressive that it is strangling the life out of us (Snyder, 2012).

"Choice" is especially important to neoliberals, and some even elevate choice to the ranks or a right or a freedom (Friedman \& Friedman, 1980). On one extreme, some neoliberals oppose any restrictions on freedom of choice and want government to let citizens choose whatever they want. Other neoliberals, meanwhile, champion a "libertarian paternalism" that tolerates some government incentives or "nudges" as they call them (Thaler \& Sunstein, 2009: p. 5). But even the self-labelled "libertarian paternalists" believe in general that people should be free to do what they like and that government should promote "freedom of choice" (Thaler \& Sunstein, 2009: p. 243).

Neoliberalism has had different spokesmen and has developed in somewhat different directions in various countries, but in the United States assorted economists, business figures, and elected officials increasingly invoked their variety of "neoliberalism" during the post-World War II decades. The influential American economist Milton Friedman, for example, used the adjective "neoliberal" in an essay published in a Norwegian business journal in 1951 (Friedman, 1951). Future Supreme Court Justice Lewis Powell authored an important confidential memorandum in 1971 for his friend Eugene Snyder, Jr., the Director of the U.S Chamber of Commerce. Powell urged Snyder and the American business community to rise up, lock arms, and defend free enterprise (Powell, 1971). Neoliberalism continued to build steam in the final decades of the twentieth century. Journalist Charles Peters published his legendary "A Neoliberal's Manifesto" in 1983 (Peters, 1983). Publications such as the The Washington Monthly and The New Republic broadcast neoliberal thought (Brooks, 2007), and rightwing think tanks and organizations such as the American Enterprise Institute, Cato Institute, Citizens for a Sound Economy, Heritage Foundation, and Institute for Economic Affairs became cozy homes for neoliberal ideologues (Monbiot, 2016).

In the realm of national politics, the first burst of neoliberal policies was perhaps President Jimmy Carter's deregulation of the airline, banking, and transport industries in the late 1970s, but deregulation greatly expanded during the Presidency of Ronald Reagan during the 1980s. Reagan also promoted tax cuts and emphasized "supply-side" economics. When Bill Clinton was elected in 1992, 
ending the so-called "Reagan-Bush Years", many were surprised that Clinton himself had a proclivity for neoliberal policies and pronouncements. He continued the deregulation initiated by his predecessors and, even more strikingly, he engineered significant reductions in American welfare programs (Albo, 2001). As for President Barack Obama, some noted with great disappointment that he sometimes followed the neoliberal trail blazed by his fellow Democrat Bill Clinton (Marcetic, 2019).

As the radical critic Noam Chomsky has noted, "[T]he term neoliberal is largely unknown and unused by the public, especially in the United States" (Chomsky, 1999: p. 7), but as is the case with ideologies in general, neoliberal ideology comes alive in its rhetoric. Neoliberals vigorously deplore "elitism", "paternalism", and the neologism "parentalism", and odd as it may seem, neoliberalism's most nefarious devil is the nanny and especially a government figuratively run by nannies, i.e., a "nanny state". A "nanny" is a person-usually a woman-who tends to somebody else's children. She does not have a familial relationship to the children as would a "granny" or grandmother, but she does typically care for the children in a loving way.

Although neoliberals invoke the notion of a nanny pejoratively, nannies are commonly portrayed in positive ways. Anglo-American literature and film, in particular, portray nannies as perky, attractive and resourceful. Too numerous to count, they include the indomitable Mary Poppins, who appeared in a series of children's books by the Australian-British writer P.L. Travers published between 1934 and 1988 and also in film musicals starring Julie Andrews, Emily Blunt, and others. Poppins's professional colleague Maria von Trapp appeared in the Broadway musical and film "The Sound of Music", and in the course of her Alpine adventures married her widowed employer before he was forced to serve in the Nazi navy. Nanny McPhee was a "government nanny" and used her mystical powers to care for a widower's seven rambunctious children in Christianna Brand's "Nurse Mathilda" stories of the 1960s and 1970s. "The Nanny" was an immensely popular American sitcom during the 1990s, in which Fran Drescher starred as Fran Fine, a brassy cosmetics saleswoman turned nanny for three high-society children. My goodness, even the anthropomorphic canine Nana in the sprawling body of works revolving around Peter Pan was a nanny. Nana was devoted to the Darling children, and in the 1953 animated film from Walt Disney Studios, she appeared wearing a cute bonnet (Kruse, 2010).

How do such positive characters become villainous in neoliberal rhetoric? How do perky, attractive, resourceful nannies become a menace? The key seems to be that the figurative nanny has come to care not for children but rather adults. In fact, she rhetorically treats those adults as children, giving them too much advice and suffocating them with her over-attentiveness.

What's more, a nefarious nanny or band of nannies has the potential to take over the government and create a "nanny state". As early as 1965, British conservative Iain Macleod, who once chain-smoked his way through a press conference disputing smoking's relationship to cancer, warned that such a coup was 
occurring in the U.K. (Daube et al., 2008). In the U.S., rightwing think tanks picked up on the phrase not long afterwards. According to the Cato Institute's Handbook on Policy.

One of the most disturbing trends in government over the last 30 years has been the collection of laws, regulations, and binding court decisions that make up the "nanny state". Those laws represent government at its most arrogant. Their message is clear: politicians and bureaucrats know more about how to live your life, manage your health, and raise your kids than you do (Cato Institute, 2005: p. 269).

Needless to say, the Cato Institute and other neoliberal think tanks want nanny-state government to be put in its place: “It's time to roll back the nanny state. Policymakers should let Americans live their lives as they please, so long as they do not harm anyone else" (Cato Institute, 2005: p. 272).

On occasion, sexism surfaces in nanny-state rhetoric, as, for example, in radio talk-show pundit Rush Limbaugh's snide comments on Michelle Obama. Her campaign for healthier foods for children, Limbaugh said with tongue firmly in cheek, reflected "the good intentions of a supposedly nice woman who's a great mother with a great garden who really cares about people" (Magnusson, 2015: p. 1082). However, the gender of almost all nannies notwithstanding, neoliberal personifications of the supposed nanny state are more likely to be male. On a website apparently devoted to collecting nanny cartoons, for example, uniformed police officers or selected politicians such as former New York City Mayor Michael Bloomberg are most likely to represent the nanny state (Cartoon Stock, 2019).

Other de facto denunciations of the nanny state include but are hardly limited to rankings of states according to how fully nannies have overtaken them. In a "study" conducted by the Cato Institute, Maine, Nevada, and New Mexico emerged as the states least overrun by nannies, with regard to restrictions on guns, use of tobacco, prosecution of victimless crimes, and so forth. The states with the least freedom, meanwhile, were, in descending order, Hawaii, Alabama, and Texas (Cato Institute, 2016). Lest any Europeans are inclined to dismiss such rankings as American silliness, the so-called "Nanny State Index" ranks 28 European Union (EU) countries. The best countries to freely eat, smoke, drink, and vape are in order Germany, the Czech Republic, and Slovakia, while Estonia, Lithuania, and Finland, in descending order, supposedly provide the least personal freedom (Snowdon, 2019).

Overall, neoliberalism is a powerful force in public debates and political disputes in the United States. Neoliberal ideology and its rhetoric appeared and took shape during the last third of the twentieth century, and in the twenty-first century, this ideology and rhetoric continue to surface in the commodities and experiences produced by the culture industry, to inspire Presidencies, and to influence legislatures and appellate courts. We should not be surprised that this ideology and its rhetoric affect law reform and law in general. 


\section{Part II: Neoliberalism and Public Health}

Neoliberal ideology and its concomitant rhetoric have predictably been important in deregulation and in the enactment of legislation weakening public labor unions, but, somewhat surprisingly, the ideology and rhetoric have also been important in efforts to reform American laws related to the public's health. Neoliberals have been especially vocal in their opposition to laws that attempt to control consumer goods or consumer behavior in order to improve the public's health. From a neoliberal perspective, these laws arguably limit freedom of choice, and they also demonstrate a misguided understanding of what lawmakers should be doing to protect the public's health. According to the Cato Handbook on Policy, "We need to rethink the idea of 'public health' so that it encompasses only serious threats to public safety such as deadly diseases or biological terrorism-threats to which no one would willingly expose themselves" (Cato Institute, 2005: p. 272).

The consequences of this opposition are significant given the nature of the nation's current health problems. In the contemporary United States, as in other affluent countries, infectious diseases have long ceased to be the greatest source of poor health. Instead, non-communicable maladies such as cancer, stroke, obesity, diabetes, hypertension, and chronic pulmonary obstruction have become the leading causes of death and disability. Although these maladies plague Americans in all walks of life, the poor and near-poor are disproportionally likely to suffer and die from them. As social epidemiologists point out, negative health outcomes almost always increase along a slope from "have-mosts" to "have-leasts" (Burris, 2011a: p. 1652). Furthermore, since poverty in the United States is semi-permanent, the poor routinely lack the resources to turn their lives around and to begin investing in healthier lives (Delgado, 2007: pp. 900-901).

Social epidemiologists have convincingly argued that an appreciation of broader historical and social factors is essential if one hopes to grapple with this imbalance in health outcomes (Krieger, 2008). One must appreciate that the collective health of a given sector of the population "is shaped to a significant degree by fundamental social conditions" (Burris, 2011b: p. 22). These social conditions include not only the physical environments and power relations but also common behaviors and activities within the given socio-economic setting. Social epidemiologists like to remind us that "place matters" in the health of a sector within the population, with "place" being understood to include not only location, neighborhood, and urban area but also race, gender, and class (Pendall, 2011: p. 1).

Health officials and self-styled progressive reformers have attempted to address American health problems and especially to correct the imbalance in health outcomes with specific laws on the local, state, and federal levels. I plan to consider only three examples: local ordinances regarding sugary soft drinks, state statues regarding motorcycle helmets, and federal laws regarding cigarette packaging. In each instance, neoliberal nanny-state rhetoric has blared loudly, warning Americans that the proposals will take away their liberty and treat them 
as children. Financially self-interested groups have often picked up the rhetoric as they oppose the proposed health law reforms. In the end, the power of the rhetoric is well illustrated by the defeat of three important law reform proposals.

1) Sugary Soft Drinks

The regulation of sugary soft drinks has caused pronounced controversy on the local level. These drinks are the largest source of added sugar in American diets, and if government could reduce the consumption of these drinks, government could theoretically begin to address American obesity and also problems associated with obesity such as heart failure, stroke, and diabetes. Hence, local reformers have attempted to restrict the sale of these drinks, to tax them heavily, and to prevent customers from using food stamps to pay for them.

Among a dozen major local controversies involving attempts to limit the consumption of sugary soft drinks, the one in New York City attracted the most attention. In 2012, Mayor Michael Bloomberg proposed that restaurants, delis, movie theaters, and sports venues be prohibited from selling sugary soft drinks in containers larger than sixteen ounces, and he asked New York City's Board of Health to endorse and implement the proposal (Grynbaum, 2012b). The Board consisted of ten members, at least five of whom were to be physicians; in addition, the ten members each had to have at least ten years of relevant experience. Since the Mayor appointed all of the members of the Board, the Board's eager approval of what came to be known as the "Big Gulp law" was virtually a foregone result ${ }^{1}$. When presenting the Big Gulp law to the public, Dr. Thomas Farley, the Commissioner of Health, blamed sugary soft drinks for up to half of the increase in obesity in New York City over the preceding 30 years (Grynbaum, 2012b). He pointed out that approximately one-third of New Yorkers drank more than one sugary soft drink a day and that both consumption and the concomitant obesity were greatest in poorer neighborhoods (Grynbaum, 2012b).

From a neoliberal perspective, meanwhile, the proposed ban was paternalistic and freedom-denying; it was a nightmarish example of the nanny state at its worst (Mitchell, 2014). My goodness, a neoliberal might complain, elites and self-styled "experts" were using the state to tell average people how much soda they could drink! Government was citing the effects of obesity as a reason "to extend its tentacles into our refrigerators and onto our dinner plates" (Cato Institute, 2005: p. 270). Some characterized the Bloomberg Administration as a "dictatorship", (Hartocollis, 2012: p. A22) and others dubbed Mayor Bloomberg "Nanny Bloomberg" (Grynbaum, 2012b: p. A1). In dozens of hostile political cartoons, Bloomberg appeared as foolish, imperious character (Cartoon Stock, 2019).

The Mayor's plan and the Board of Health's endorsement of it also "prompted panic among powerful beverage companies, which feared their products would be branded as a threat to public health" (Grynbaum, 2014: p. A24). The industry

${ }^{1}$ The proposal was approved by a vote of 8-0 with one abstention (Grynbaum, 2012a). The "Big Gulp" label derived from the infamous 32-ounce "Big Gulp" sold at 7-Eleven convenience stores. The stores also sell the 44-ounce "Super Big Gulp” and the 64-ounce "X-Treme Gulp” (Klara, 2012). 
thought the Big Gulp law would be bad for business and "poured millions of dollars into an ad campaign that framed the proposal as infringing on consumer freedom" (Grynbaum, 2014: p. A24) ${ }^{2}$. In addition to its advertising campaign, the beverage industry also challenged the Big Gulp law in court.

In particular, the American Beverage Association, which represented beverage companies and franchises in multiple states, initiated a lawsuit and also recruited a group of co-plaintiffs. The latter bear listing because one might easily misunderstand who was challenging the "Big Gulp" law in court. In addition to the American Beverage Association, the plaintiffs included the New York Statewide Coalition of Hispanic Chambers of Commerce, representing nearly 200,000 Hispanic businesses; the New York Korean-American Grocers Association, representing nearly 4000 Korean grocery and deli owners; the National Association of Theatre Owners of New York State, representing 52 movie theaters with 312 screens; the National Restaurant Association, representing almost 700 restaurants in New York City; and the Soft Drink and Brewery Workers Union, Local 812 of the International Brotherhood of Teamsters, representing employees who did hauling, warehousing, and distribution work for the soft drink companies. In a later opinion from the New York Court of Appeals, Judge Eugene F. Pigott, Jr. misleadingly characterized the plaintiffs as "six national or statewide not-for-profit and labor organizations" (New York State Coalition of Hispanic Chambers of Commerce, 2014: p. 691), but in reality, the plaintiffs represented business and employee groups with direct and indirect financial reasons in preventing the "Big Gulp" law from taking effect. None of the plaintiffs were primarily interested in the health of New York City consumers.

The plaintiffs prevailed in the trial court, and also in two appeals pursued by the New York City Department of Health and Mental Hygiene. In each instance, the prevailing argument was that the Board of Health had exceeded the scope of its regulatory authority and infringed on the legislature's powers. The trial and appeals courts all cited as the key precedent a 1987 decision that had invalidated an administrative attempt to ban smoking inside certain establishments (Boreali, 1987). In the opinion of each court that considered the case, Bloomberg's plan was invalid and its enforcement should be permanently enjoined.

As one might perhaps anticipate, the opinions grew increasingly rule-bound and rarefied as the case moved from the trial court to the Appellate Division of the Supreme Court to the Court of Appeals of New York. Hints of a receptiveness to neoliberal ideology and rhetoric are present on each level, but the trial-court decision by Judge Milton A. Tingling shows the most receptiveness, although Tingling does not explicitly refer to neoliberalism or employ the most common varieties of nanny-state rhetoric.

Tingling tips his hand early in his opinion when he launches what turns out to

${ }^{2}$ The beverage industry has spent heavily in other cities to stop legislation designed to reduce consumption of sugary soft drinks. For example, the industry spent $\$ 7.7$ million on an advertising campaign to derail proposed soda taxes in San Francisco, California and another \$1.4 million for the same purposes in nearby Berkeley, California (Nagourney, 2014). 
be a gratuitous attack on the Board of Health's use of the terms "epidemic" and "obesity". "The words 'epidemic' and 'obesity", Tingling observed, "are neither examined nor explained as much as they are stated as fact" (New York State Coalition of Hispanic Chambers of Commerce, 2013: p. 6). He then proceeded to provide the definitions of the terms from Webster's Dictionary before acknowledging that the plaintiffs did not even dispute the use of the terms and decreeing that questions regarding epidemics and obesity need be discussed no further. Tingling's goal in this portion of his opinion, be it conscious or unconscious, seems chiefly to have been the undermining of the Board of Health's expertise and reliability.

If the Board of Health was allowed to ban Big Gulps, Tingling thought, the Board of Health would have staked out "virtually limitless authority" (New York State Coalition of Hispanic Chambers of Commerce, 2013: p. 34). The Board of Health would have the authority "to define, create, mandate and enforce limited only by its own imagination" (New York State Coalition of Hispanic Chambers of Commerce, 2013: p. 35). Indeed, the "Big Gulp" provision, if upheld, "would create an administrative Leviathan... (New York State Coalition of Hispanic Chambers of Commerce, 2013: p. 35). The Board of Health would be a giant, menacing arm of government, which, in the opinion of some, had itself already grown too big and intrusive.

When Tingling's decision was confirmed in two subsequent appeals, a chastised Mayor Bloomberg and his obedient Board of Health declined to pursue the matter any further. Bloomberg admitted that the "Big Gulp" plan was hardly a panacea for obesity problems among the poor and near-poor. The proposed provision in the Health Code, he said, was really only a "speed bump", designed to get New Yorkers to slow down in the buying and drinking of sugary soft drinks (Friedman, 2014: p. 1739). The attempted ban on sugary soft drinks was more than that, neoliberals and the American Beverage Association might have said. The plan was an example of the improper excesses of the nanny state, and it would have "limited New Yorkers' freedom of choice" (Grynbaum, 2014, p. A24).

2) Motorcycle Helmets

Little doubt exists that motorcycle riding is dangerous and that wearing a proper helmet can reduce the danger. According to one study, a startling one in seven traffic deaths involves motorcycle crashes (Schmitt, 2012). Helmets could have prevented many of these deaths because they are highly effective in protecting motorcycle riders' heads when accidents occur. According to the Centers for Disease Control and Prevention, helmets reduce motorcycle rider fatalities by 22 to 42 percent and brain injuries by 41 to 60 percent (Centers for Disease Control and Prevention, 2016). One trauma room physician speaking on behalf of the National Highway Traffic Safety Administration (NHTSA) has compared helmets to "a vaccine" because of the compelling evidence they reduce brain injuries for motorcycle riders (Schmitt, 2012).

With increasing evidence of how dangerous motorcycle riding was and how 
useful helmets could be, the United States Congress in 1966 enacted the National Traffic and Motor Vehicle Safety Act. The Act provided funding to the states for taking steps thought to improve traffic safety, e.g., better accident records, improved traffic control systems, and more detailed vehicle registration. In order to receive the funding, a state needed first to enact a law requiring motorcycle riders to wear helmets (Eltorai et al., 2016). Unwilling to turn their backs on federal funding for traffic safety, the states willingly enacted the required helmet laws; by 1975, 47 states and the District of Columbia had enacted laws requiring motorcycle riders to wear a helmet (Centers for Disease Control and Prevention, 2016).

The laws made motorcycle-riding safer, but neoliberals were immediately up in arms. Their complaints regarding the helmet laws varied. Some said helmets were too expensive. Others challenged the research about injuries and deaths resulting from the crashes. Far and away the loudest neoliberal complaint was that the helmet laws impinged on individual rights and personal freedom. For some of the complainers, the helmet laws were nanny-state initiatives designed to limit freedom of choice through unwarranted government intervention. One spokesman for the Cato Institute characterized the helmet laws that came on the books in the 1970s as a leading example of government policy that unduly regulated personal behavior and lifestyle (Balko, 2006). Riding a motorcycle without a helmet, another Cato Institute spokesman more recently admitted, may be bad for an individual, but he also argued riding without a helmet does not become a genuine public health issue just because lots of people do it (Boaz, 2013). From a neoliberal perspective, the helmet requirements illustrated that, "The meaning of 'public health' has sprawled out lazily over the decades"' (Boaz, 2013).

The groups and organizations most likely to pick up and reiterate the neoliberal rhetoric were assorted motorcycle-rider clubs and organizations. According to National Motorists Association (NMA), an organization that works for the rights of motorists including motorcycle riders, the helmet laws were "entirely arbitrary interferences with personal choice" (Peters, 2020). "Busybodies and do-gooders", the NMA thought, were using "the force of government as their cudgel..." (Peters, 2020) ${ }^{3}$.

Why would motorcycle groups and organizations be so opposed to helmets? One might have thought that riders' safety would have been their chief concern, but the subculture of motorcycle riding has never fully embraced wearing helmets and riding safely. This is perhaps most obvious among the so-called "outlaw" motorcycle gangs such as the Hells Angels, Pagans, Outlaws, and Bandidos. Their recklessness and violent behavior are so pronounced as to have resulted in special instructions for hospital emergency room personnel whenever "outlaw" riders present themselves for care (Bosmia et al., 2014).

To be sure, these "outlaw" riders do not represent the attitudes and values of motorcyclists as a whole and are sometimes known as "one-percenters" among

${ }^{3} \mathrm{~A}$ cudgel, by the way, is a short, thick stick used to beat someone. 
motorcycle enthusiasts (Thompson, 2008: p. 89). Yet even for the great majority of motorcycle riders, for whom motorcycle-riding is less a working-class subculture and more a middle-class hobby or avocation, helmets are often unpopular. Motorcyclists want to "embrace the ride", and they are leery, even a bit paranoid, about any attempts to restrict their perceived freedoms (McCrystal, 2014).

These sentiments are evident in the statements of the American Motorcyclist Association (AMA) which has insisted for decades that "every motorcyclist with red blood in his veins" wants the highways to remain free and open (American Motorcyclist Association, 2018). The Legislative Department of the AMA has taken itself to be "a sentinel" for discriminatory federal and state legislation related to motorcycle riding, and the Legislative Department is on record to the effect that a law requiring helmets for motorcycle riders is just such discriminatory legislation (American Motorcyclist Association, 2018). "Many motorcyclists view the helmet as an accessory of personal apparel", the AMA noted, "and its use or non-use is connected with a chosen lifestyle and their right as adults to make their own decisions" (American Motorcyclist Association, 2014).

Assorted motorcycle clubs and organizations not surprisingly sued to stop enforcement of state helmet laws. A few courts found these laws unconstitutional, but in general, these decisions were reversed or overruled. The most important decision regarding the constitutionality of the helmet laws grew out of a challenge to Florida's statute requiring motorcycle riders to wear both a helmet and an eye-protecting shield. Motorcyclist David L. Picou claimed, among other things, that the statute unduly infringed his right of privacy. Having lost in the district court, he then appealed to the United States Court of Appeals for the Eleventh Circuit. The Court rudely reminded Picou that although a right of privacy surely existed, "There is little that could be termed private in the decision whether to wear safety equipment on the open road. Indeed, the Supreme Court has repeatedly declined to recognize a constitutional right that would cover appellant's case" (Picou, 1989: p. 1521). As for the appellant's more general argument that the Florida statute was "paternalistic" and violated his "right to be let alone", the Court was even more disdainful (Picou, 1989: p. 1521). The Court quoted approvingly American constitutional law luminary Laurence Tribe: “[I]n a society unwilling to abandon bleeding bodies on the highway, the motorcyclist or driver who endangers himself plainly imposes costs on others" (Tribe, 1988: 1372).

Subsequent judicial decisions also rejected the arguments of neoliberals and assorted opponents of the helmet laws (ABATE, 2001), but the neoliberals and assorted motorcycle organizations also lobbied Congress in hopes of achieving regulatory and legislative changes. The AMA, whose corporate members include not only the American powerhouse Harley-Davidson but also Japanese motorcycle manufacturers Honda, Kawasaki, Suzuki, and Yamaha, spent \$3.8 million lobbying Congress on helmet laws and other issues during 2003-2012 (Schmitt, 2012). The Motorcycle Riders Foundations spent \$2.1 million lobbying during 
the same decade (Schmitt, 2012).

The federal legislator who was and remains most receptive to the arguments of the helmet law opponents is United States Congressman Jim Sensenbrenner of Wisconsin. Sensenbrenner represents the western and northern suburbs of Milwaukee as well as part of Wisconsin's rural Jefferson County, and he served in Congress for over 40 years before announcing his plans to retire in 2020. His home state of Wisconsin boasts a large corps of avid motorcycle riders, including former Governor Scott Walker, and the state is in general enamored with motorcycle culture. Sensenbrenner himself lives in the Milwaukee suburb of Menomonee Falls, the location of the large Harley-Davidson powertrain plant.

Sensenbrenner has not focused only on helmet laws while serving in Congress, and like a good number of other contemporary members of Congress, his most pointed purported concern in the present is the opioid crisis. But still, motorcycle riders have long looked to Sensenbrenner as a champion. With Sensenbrenner's urging, Reagan-Bush regulators eager to reduce the presence of government dropped the requirement that a state has a universal helmet law in order to receive traffic safety funds. Sensenbrenner also spearheaded a drive in the United States Congress to reduce testimony about the need for helmet laws before state legislatures, especially from representatives of the NHTSA. Sensenbrenner's "gag rule" said NHTSA spokesmen could still appear before state legislatures only if formally invited (Schmitt, 2012). Even in more recent years, Sensenbrenner strongly endorsed the effort to prevent federal funds from being used for motorcycle checkpoints at which police would check to see if helmets met safety specifications. Not surprisingly, Sensenbrenner has consistently received larger annual contributions from the AMA than any other government official (Open.Secrets.Org, 2018).

With highway regulators amenable and the likes of Congressman Sensenbrenner ever-vigilant regarding motorcyclists' "freedom", the number of states with laws requiring all motorcycle riders to wear helmets dropped from 47 to 19 (Insurance Institute for Highway Safety, 2008). A slight majority of the states settled for helmet requirements for riders and passengers below a given age, most commonly 18 (Insurance Institute for Highway Safety, 2008). Three states (Illinois, Iowa, and New Hampshire) dropped helmet laws completely (Insurance Institute for Highway Safety, 2008).

The story of thwarted law reform regarding motorcycle helmets on the state level is more striking than the failed law reform regarding sugary soft drinks on the local level. There is, after all, strong evidence that motorcycle helmet laws reduce the number and severity of head injuries from accidents (National Highway Traffic Safety Administration, 1996). Motorcycle helmet laws also save lives. During the first fifteen years of the twenty-first century, while most states backed off legislation requiring motorcycle riders to wear helmets, deaths from motorcycle crashes more than doubled (Schmitt, 2012).

Furthermore, it does not suffice for motorcyclists to say they are willing to 
take the risk and pay the price because many of the costs associated with a motorcycle accident fall on family members or the government. Data show that only one-half of all motorcyclists have medical insurance, and as a result the costs of hospitalization and long-term medical care will often be paid by family members or through government programs (National Highway Traffic Safety Administration, 1996). Then, too, it is expensive to die in a motorcycle crash. Families lose the income of the deceased, accident-related claims drain away assets, and loved ones usually pay funeral expenses, which in the present average more than $\$ 10,000$ per person (Buck \& Winegar, 2016). One study compared costs between states with mandatory helmet laws to those with states that had repealed their laws and found differential costs amounting to more than $\$ 412.9$ million (Eltorai et al., 2016).

But alas, unambiguous data proved little match for neoliberal glorification of individual choice and the freedom it connotes. Motorcyclists' clubs and organizations knowingly or unknowingly employed that rhetoric to challenge the laws supposedly being foisted on them by what they considered the nanny state. Legislators anxious to please the motorcycle lobby then repealed or modified laws requiring helmets. Assorted doctors, public health officials, and federal regulators were unable to stem the reactionary tide.

3) Cigarette Packaging

Despite extensive anti-smoking campaigns launched by public health officials, tobacco use and especially cigarette smoking remain serious health problems in the United States. The nicotine in tobacco products is highly addictive, and smoking causes or contributes to over a dozen types of cancer as well as to bronchitis, chronic pulmonary obstruction, and vascular disease. Approximately 15\% of adults or more than 36 million Americans continue to smoke, and about half of these people will die prematurely unless they stop smoking (Fiore, 2016: p. 1412). The United States Supreme Court itself has observed that "tobacco use, particularly among children and adolescents, poses perhaps the single most significant threat to public health in the United States" (FDA v. Brown \& Williamson, 2000: p. 161).

Ever since the Surgeon General confirmed in 1964 that cigarette smoking caused cancer, local, state, and federal governments have made numerous efforts to discourage people from smoking. A good number of these efforts have involved notices and warnings on cigarette packages (Weatherby \& Day, 2012). These notices and warnings have presumably contributed to the declining smoking rates in the United States, but the tobacco industry has offered strong resistance to anti-smoking campaigns, often through lobbying and through campaign contributions to elected officials who support the tobacco industry (Open.Secrets.Org, 2020) $)^{4}$. Indeed, the Food and Drug Administration (FDA) has lamented that its struggle against the tobacco companies is "like bringing a butter knife to a gun fight" (Reynolds, 2012: p. 1221).

${ }^{4}$ As of 2016, tobacco companies had given $\$ 63$ million to state candidates, committees, and ballot initiatives during the preceding five years (Kusnetz, 2016). 
The Family Smoking Prevention and Tobacco Control Act (FSPTCA) of 2009 was a major effort by the federal government to reduce smoking in the general population and particularly among teenagers. The FSPTCA is massive legislation, but the feature that provoked the greatest controversy was a directive to the FDA to develop nine color graphics that would depict the negative health consequences of cigarette smoking. The graphics were to accompany nine statutorily-prescribed warnings and to cover at least half of the back of individual cigarette packages. Pursuant to the statutory directive, the FDA produced thirty-six potential images and then conducted an 18,000-person survey to determine which of the graphics most successfully increased viewers' intention to quit smoking, expanded smokers' knowledge of the health risks associated with smoking, and/or caused those who viewed the graphics to feel "depressed", "discouraged", or "afraid". The FDA then reviewed over a thousand comments on the proposed graphics before settling on the nine that would appear on cigarette packages.

Although the selection of the nine graphic images was an innovation in the United States, it was not unusual on the world stage. Requiring graphic images on cigarette packages is consistent with the World Health Organization's Framework on Tobacco Control, (World Health Organization, 2003) and, starting with Iceland in 1985, many countries had already required comparable graphic images. A range of empirical studies, after all, has "demonstrated the superiority of using pictures and imagery over text-only messages in health communication" (Fong et al., 2009: p. 641). So-called "fear appeals", it appears, are much more effective in getting smokers to quit, particularly if information about how to avoid the "fearful" consequences is coupled with graphic images (Fong et al., 2009: p. 641). The graphic images with accompanying written warnings may be especially important in communicating with populations with lower literacy levels, a relevant consideration since smoking in the United States is increasingly concentrated within impoverished and working-class sectors of the population, in which lower literacy levels are prevalent.

When the FDA revealed the final nine graphic images, neoliberal ideologues were not surprisingly outraged at the images of rotted teeth, diseased lungs, and nicotine-addicted people smoking through holes in their tracheas. Images such as these, argued Sam Kazan, General Counsel for the Competitive Enterprise Institute, a free-market advocacy organization, was still another attempt, "to shout louder at people and gross them out in hopes of getting them to act in a certain way" (Fox News Network, 2010). Jeff Jacoby, writing in The Boston Globe, conjured up the type of slippery slope so common in ideological rhetoric:

Should the manufacturer's sticker on every new car be required to include images of horrible collisions and mangled motorists? Should packages of high calorie junk food depict rolls of flabby cellulite or a patient undergoing bypass surgery? Should beer and wine bottles be covered with grisly pictures of ruined livers or passed-out drunks? (Jacoby, 2010). 
The federal government, Jacoby continued, should not be treating adults like they were children, and in his opinion we surely did not want to entrust the Department of Health and Human Services with stomping out our bad personal habits. "The nanny-state makes some decisions easier", he admitted, "but it is not compatible with a free society" (Jacoby, 2010).

"Big Tobacco"-as the larger American cigarette companies have come to be known colloquially-was also outraged, albeit for a more obviously self-interested reason. The graphic images might reduce the number of smokers, and fewer smokers would lead to reduced sales and less profit. Of course, Big Tobacco would not make that argument directly. Since the late-1960s, though, the tobacco industry has argued that Americans have the "freedom to smoke" (Tobacco Tactics, 2016). The industry has even funded smokers' rights groups that are prepared to make this argument on behalf of the tobacco industry. More generally, the industry has consistently attempted to shift the public's focus from cigarette smoking's relationship to health to modern government's assault on personal liberty. Graphic images, the industry was prepared to say, get in the way of freedom and individual choice.

In addition to publicly protesting the requirement that graphic images be placed on cigarette packages, Commonwealth Brands, the Liggett Group, Lorillard Tobacco, R.J. Reynolds, and Santa Fe Natural filed suit in the United States District Court for the District of Columbia. The suit looked less to smokers' rights than to the rights of the tobacco industry. In particular, the suit argued that the FDA's actions violated the companies' First Amendment protections. According to well-established precedent, these protections included not only the right to say what one wanted but also the right to refrain from saying what one did not want to say (Wooley, 1977). The District Court was receptive to the tobacco companies' arguments. It first enjoined the FDA from requiring the graphic images and then granted the companies motion for summary judgment (Reynolds, 2012). According to Maureen Martin, a senior fellow at The Heartland Institute, a libertarian and conservative think tank based in Illinois, the decision was a great victory for anyone "living in the slavery imposed by the $24 / 7$ Nanny State" (Karmasik, 2019).

On appeal, the companies attracted impressive counsel and high-powered amici. They retained lawyers from some of the largest and most respected law firms in the country: Cahill Gordon \& Reidel, Covington \& Burling, Jones Day, Latham \& Watkins, and O’Melveny \& Myers. Amicus briefs were filed by the American Advertising Foundation, the Association of National Advertisers, and the Chamber of Commerce, as well as by the Washington Legal Foundation, a conservative think tank and promoter of pro-business and free-market positions. The FDA, meanwhile, relied on government lawyers to argue its case, but it did attract amicus briefs from important health organizations: the American Academy of Pediatrics, the American Cancer Society, the American Heart Association, the American Lung Association, the American Medical Association, and the American Public Health Association. 
The tobacco companies' sophisticated appellate brief maintained the previously articulated position that the companies' First Amendment protections were being violated, and the U.S. Court of Appeals ultimately agreed with Big Tobacco. The Court determined that the FDA's required graphic images requirement should be reviewed using the intermediate standard for commercial speech as stated in Central Hudson Gas \& Electric Corp. v. Public Service Commission (Central Hudson Gas \& Electric, 1980). Under that standard, the government had to demonstrate it had an important goal and that its means were narrowly tailored to reach that goal. While the FDA's goal of reducing smoking rates was demonstrably important, the Court concluded that the FDA had not produced enough evidence that the graphic warnings would "directly" reduce smoking by a "material degree". As a result, the requirement that graphic images appear on individual cigarette packages was an unconstitutional limitation on the tobacco companies' commercial speech.

Most of the Court's opinion was a rather prosaic interpretation and discussion of levels of constitutional scrutiny for commercial speech, but the Court certainly made clear how little it thought of the FDA's approach and its justifications for graphic images on cigarette packs. The Court stated that the FDA had not provided "a shred of evidence" that graphic warnings would actually reduce the number of smokers (Reynolds, 2012: p. 452). Furthermore, the Court said that while some Canadian and Australian studies indicated that large graphic warnings might induce individual smokers to reduce consumption, the studies "did not purport to show that the implementation of large graphic warnings has actually led to a reduction in smoking rates" (Reynolds, 2012: p. 452). Overall, according to the Court, the FDA had relied on "questionable social science (Reynolds, 2012: p. 452).

While the Court of Appeal's discussion of levels of scrutiny regarding commercial speech and critique of the FDA's justifications for graphic images did not feature neoliberal rhetoric, the Court's protection of the companies' speech rights in the market context undoubtedly warmed the neoliberal heart. Indeed, the legal scholar Professor David Orentlicher has cited the R.J. Reynolds decision as a primary example of the federal courts' growing willingness to "protect" businesses' commercial speech rights (Orentlicher, 2013: p. 204). And as the federal courts widen the business sector's freedom to advertise, Orentlicher says, the courts have narrowed government power to preserve the public's health. There was once a time when the courts gave the government more leeway with regard to public health matters, but the courts now tend to treat health-related rules the same way as other rules.

While neoliberal ideologues would have delighted in the expansion of First Amendment protections for commercial speech, these ideologues might also have wondered if the R.J. Reynolds decision would stick. For one thing, a three-judge panel of the U.S. Court of Appeals for the Sixth Circuit upheld the provisions of FSPTCA that directed the FDA to select and require graphic warnings for individual cigarette packages. The panel thought the Act did not 
impose undue burdens on the plaintiffs' commercial speech (Discount Tobacco City \& Lottery, 2012). Then, too, the same U.S. Court of Appeals for the District of Columbia which issued the R.J. Reynolds decision subsequently said the less stringent rational-basis review could be used for scrutinizing regulations in some cases (American Meat Institute, 2014). This overruled a narrower interpretation of the Supreme Court's holding in Zauderer v. Office of Disciplinary Council of the Supreme Court of Ohio (Zauderer, 1985).

Despite the conflicting and confusing case law, the FDA failed to appeal R.J. Reynolds to the Supreme Court or to promptly issue a newer, less frightening set of graphic images for individual cigarette packages. It was almost as if the neoliberal blustering, judicial skepticism regarding the FDA's social science, and the federal courts' growing fondness for commercial speech froze the FDA. In fact, the FDA's caution struck some as so inept and irresponsible that they tried to force the FDA's hand. The American Cancer Society, American Cancer Society Action Network, American Heart Association, American Lung Association, and the Campaign for Tobacco-Free Kids asked a federal court to give the FDA a firm deadline for issuing new and presumably constitutional graphic images (Jenco, 2018).

Finally, in August of 2019, the FDA released thirteen new graphic images that could ultimately be required for cigarette packages and advertising (U.S. Food \& Drug Administration, 2019). The images and their accompanying messages were to take up half of a package's front and back. The public was free to comment on the proposed packaging during the final months of 2019, with the final FDA proposal to be submitted in March, 2020. Assuming no delays, the new packaging could begin appearing fifteen months after that (Bever, 2019).

Perhaps the FDA's new research and development will satisfy the courts this time around, and the United States will join the 120 countries worldwide that already require graphic images on their cigarette packaging. If this comes to pass, neoliberals might think it is still another example of the nanny state shouting at us. But friends and family members of the 480,000 people who die annually from smoking might wish the shouting had been even louder, assuming of course that they themselves had heeded the warnings regarding cigarette smoking.

\section{Conclusion}

My goal in this article has not been to take sides in the specific debates regarding sugary soft drinks, motorcycle helmets, or cigarette packaging, although I suspect my preference in each of these areas is clear. My overall goal instead has been to explore the effects of neoliberalism in attempts at law reform related to the public's health. As indicated above, neoliberal ideology and its concomitant rhetoric have influenced legislative and judicial thinking and in some instances brought law reform to a grinding halt, much to the detriment of the public's health. If raised to higher relief, neoliberalism's ability to impede law reform in the United States might yield insights about the relationship of ideology and law 
in general.

What have we learned about the workings of ideology in law reform? For starters, it is worth repeating that although ideology, as a normatively-imbued cluster of ideas and concepts, exists in and of itself, it comes to life through its related rhetoric. Few Americans would recognize neoliberalism's abstracted representations of government, the economy, and society in general, but the notion of a "nanny state" is most likely to ring a bell. Odd as it might seem given the appealing image of nannies in popular culture, some Americans find the notion of a "nanny state" menacing.

Furthermore, ideological rhetoric might obscure an ideology's relationship to socioeconomic actors and causes. Ideological rhetoric, in other words, has the power not only to provoke and inspire people but also to be useful to groups and interests that adopt the rhetoric and employ it for their own purposes. In the area of American health law reform, it is particularly clear how enamored business interests are with neoliberal rhetoric and how prepared they are to use it in advancing their interests. The beverage industry, motorcycle manufacturers, and of course Big Tobacco have employed nanny-state rhetoric to counter law reform proposals that might threaten their profits. To put it bluntly, neoliberalism's rhetoric provides a façade behind which big business can pursue its goals.

Most importantly-and most disturbingly—neoliberal ideology and its concomitant rhetoric, with their emphasis on individual choice and freedom, are unmindful of the socio-economic context of many contemporary public health problems. Neoliberal ideologues, for starters, do not recognize the way powerful business interests themselves severely restrict freedom of choice in their presentation and pricing of product lines. Neoliberals, in this sense, do not think much about inequality and about the vulnerability of the less fortunate to market forces. More generally, they do not appreciate (or want to acknowledge) that the health of the public is a collective, social phenomenon.

Associate Justice Lewis Powell seemed to grasp what the neoliberals overlook in his opinion for the Court in Picou. In response to the argument that motorcycle helmets law is invalid because of their paternalism, Powell pointed out that motorcyclists do not ride in isolation:

The helmet requirement does not implicate the appellant alone. Motorcyclists normally ride on public streets and roads that are maintained and policed by public authorities. Traffic is often heavy, and on highways proceeds at high rates of speed. The required helmet and faceshield may prevent a rider from becoming disabled by flying objects on the road, which might cause him to lose control and involve other vehicles in a serious accident

(Picou, 1989: p. 1521).

Powell then went on to point out that the costs of an injury to a motorcyclist without a helmet are likely to be borne by the public. "State and local government provide police and ambulance services, and the injured cyclist may be hospitalized at public expense", he noted. "If permanently disabled, the cyclist could 
require public assistance for many years" (Picou, 1989: p. 1521).

Comparable observations could be made about drinking excessive amounts of sugary soft drinks or smoking cancer-causing cigarettes. Sugary soft drinks contribute to obesity, which in turn is a factor in diabetes and other health problems. Family members and the state often take on associated expenses. The second-hand smoke from smoking can be unhealthy for family members and close friends, and the expenses related to a smoker's virtually inevitable health problems will have to be paid for by somebody. Then, too, watching a loved one waste away from cancer takes a toll on family and friends that is difficult to reduce to a monetary figure. In its opposition to health law reform in these areas and others, neoliberals are oblivious to the socioeconomic dimensions and costs related to what they take to be the exercise of freedom.

When priding themselves on their ability to live by the proverbial rule of law rather than the rule of men, Americans often imagine a law that is fixed and stands firmly in place (Papke, 2015: pp. 223-225). However, law reform is also a mainstay in the law, and the process of law reform illustrates how fluid and malleable law customarily is. Ideologues of one stripe or another are constantly attempting to change the law, and they often succeed in their efforts. Their ideologies and related rhetorics play significant roles in the law-reform process, and it would be naïve to think otherwise.

\section{Acknowledgements}

The author thanks Scott Hyman, Marquette Law '19, and Amanda Meyers, Marquette Law '21, for their excellent research assistance.

\section{Conflicts of Interest}

The author declares no conflicts of interest regarding the publication of this paper.

\section{References}

Albo, G. (2001). Neoliberalism from Reagan to Clinton. Monthly Review, 52, 81-89. https://doi.org/10.14452/MR-052-11-2001-04_7

Althusser, L. (1971). On the Reproduction of Capitalism: Ideology and Ideological Apparatuses. London: Verso.

American Motorcyclist Association (2014). AMA Position in Support of Voluntary Helmet Use.

https://www.americanmotorcyclist.com.About-the-AMA/voluntary-helmet-use-1

American Motorcyclist Association (2018). History of the AMA. http://www.americanmotorcyclist.com/About-the-AMA/Story/history-of-the-ama

Balko, R. (2006). Myths of the Nanny State. https://www.cato.org./policy-report/septemberoctober-2006/myths-nanny-state

Bever, L. (2019). FDA's New Cigarette Warnings Are Scary. That's the Point. Washington Post.

https://www.wasingtonpost.com/health/2019/08/15/fda-proposed-new-cigarette-warni 
ngs-are-scary-that's-the-point

Boaz, D. (2013). What Is Public Health? Cato at Liberty. https://cato.org/blog/what-is-public-health

Bosmia, A. et al. (2014). Outlaw Motorcycle Gangs: Aspects of the One-Percenter Culture for Emergency Personnel to Consider. Western Journal of Emergency Medicine, 15, 523-528. https://doi.org/10.5811/westjem.2014.2.17919

Brockway, L. H. (2016). 10 Rhetorical Devices Used in Political Messages. Ragan. https://www.ragan.com.10-rhetorical-devics-used-in-political-messages

Brooks, D. (2007). The Vanishing Neoliberal. New York Times, 11 March 2007, WK14.

Buck, V., \& Winegar, J. (2016). What Should I Expect to Pay for Funeral and Burial EXpenses?

https://www.longtermcarelink.net/article-2016-2-16-what-should-I-expect-to-pay-for-f uneral-and-burial-expenses.html

Burris, S. (2011a). From Health Care to the Social Determinants of Health. University of Pennsylvania Law Review, 159, 1649-1667.

Burris, S. (2011b). Law in a Social Determinants Strategy. Public Health Reports, 126, 22-27. https://doi.org/10.1177/00333549111260S305

Cartoon Stock (2019). Nanny State Cartoons and Comics. https://www.cartoonstock.com/directory/n/nanny_states.asp

Cato Institute (2005). Cato Handbook on Policy (6th ed.). Washington DC: Cato Institute.

Cato Institute (2016). Freedom in the 50 States. https://www.freedominthe50states.org/personal

Centers for Disease Control and Prevention (2016). Universal Motorcycle Helmet Laws. https://www.cdc.gov/motorvehiclesafety/calculator/factsheet/mhelmet.html

Chomsky, N. (1999). Profit Over People: Neoliberalism and the Global Order. New York: Seven Stories Press.

Condor, S. et al. (2012). Political Rhetoric. In L. Huddy (Ed.), Oxford Handbook of Political Psychology (pp. 262-297). Oxford: Oxford University Press.

Daube, M., Stafford, J., \& Bond, L. (2008). No Need for Nanny. Tobacco Control, 17, 426-427. https://doi.org/10.1136/tc.2008.027763

Delgado, R. (2007). The Myth of Upward Mobility. University of Pittsburgh Law Review, 68, 879-901. https://doi.org/10.5195/LAWREVIEW.2007.76

Eagleton, T. (1991). Ideology-An Introduction. London: Verso.

Eltorai, A. et al. (2016). Federally Mandating Motorcycle Helmets in the United States. BMC Public Health, 16, Article No. 242.

https://www.ncbi.nlm.nih.gov/pubmed/26955806

https://doi.org/10.1186/s12889-016-2914-3

Fiore, M. C. (2016). Tobacco Control in the Obama Era-Substantial Progress, Remaining Challenges. The New England Journal of Medicine, 375, 1410-1412. https://doi.org/10.1056/NEJMp1607850

Fong, G. T., Hammond, D., \& Hitchman, S. C. (2009). The Impact of Pictures on the Effectiveness of Tobacco Warnings. Bulletin of the World Health Organization, 87, 640-643. https://doi.org/10.2471/BLT.09.069575

Fox News Network (2010). FDA's Graphic Warnings for Cigarettes: Noble Ad Campaign or Nanny State at Work?

https://www.foxnews.com/politics/fdas-graphic-warnings-for-cigarettes 
Friedman, D. A. (2014). Public Health Regulation and the Limits of Paternalism. Connecticut Law Review, 46, 1687-1773.

Friedman, M. (1951). Neoliberalism and Its Prospects. Farmand, 17 February 1951, 89-93.

Friedman, M., \& Friedman, R. (1980). Free to Choose-A Personal Statement. San Diego, CA: Harcourt.

Giroux, H. (2008). Against the Terror of Neoliberalism-Politics beyond the Age of Greed. London: Routledge.

Grynbaum, M. (2012a). Health Panel Approves Restrictions on Sale of Large Sugary Drinks. New York Times, 14 September 2012, A24.

Grynbaum, M. (2012b) Mayor Planning a Ban on Big Sizes of Sugary Drinks. New York Times, 31 May 2012, A1.

Grynbaum, M. (2014). Court of Appeals, Ruling 4-2, Ends City's Fight to Limit Size of Sugary Drinks. New York Times, 6 June 2014, A24.

Hartocollis, A. (2012). To Gulp or to Sip? New York Times, 1 June 2012, A22.

Hoffer, E. (1951). The True Believer: Thoughts on the Nature of Mass Movements. Harper Perennial, New York.

Insurance Institute for Highway Safety (2008). Motorcycle Helmet Use. https://www.iihs.org/iihs/topics/laws/helmetuse/helmethistory/topic

Jacoby, J. (2010). Warning Labels and the Nanny State. The Boston Globe. https://www.jeffjacoby.com/8342/warning-labels-and-the-nanny-state

Jenco, M. (2018). Judge Orders FDA to Speed up Graphic Warnings Requirements for Cigarettes. AAP News. https://www.aappublications.org.news

Karmasik, J. M. (2019). Stay Order Against New Cigarette Warning Labels. Legal Newsline.

https://legalnewsline.com/stories151052800-stay-ordered-against-new-cigarette-warni ng-labels

Klara, R. (2012). The Tall, Cold Tale of the Big Gulp. Adweek. https://www.adweek.com/brandmarketing/tall-cold-tale-big-gulp-162960

Krieger, N. (2008). Proximal, Distal, and the Politics of Causation. American Journal of Public Health, 98, 221-230. https://doi.org/10.2105/AJPH.2007.111278

Kruse, G. (2010). 10 Famous Nannies. Care.Com, Inc. https://www.care.com/c/stories/2723/10-famous-nannies

Kusnetz, N. (2016). How Big Tobacco Lobbies to Safeguard E-Cigarettes, Center for Public Integrity.

https://www.publicintegrity.org/politics/state-politics/how-big-tobacco-lobbies-to-safe guard -e-cigarettes/

Magnusson, R. S. (2015). Case Studies in Nanny State Name-Calling: What Can We Learn? Public Health, 129, 1074-1082. https://doi.org/10.1016/j.puhe.2015.04.023

Marcetic, B. (2019). How Obama Failed. Jacobin.

https://www.jacobinmag.com/2019/05/obama-white-house-financial-crisis-hundt

McCrystal, H. (2014). The History of Motorcycle Culture. Motor Bike Times. https://www.motorbiketimes.com/feature/the-history-of-motorcycle-culture $\$ 21384141$ . htm

Mitchell, D. (2014). Taxing Drinks Gives Pols a Sugar Rush. Fortune. https://www.fortune.com/retail/2014107/soda-tax-san-francisco

Monbiot, G. (2016). Neoliberalism-At the Root of All Our Problems. The Guardian. https://www.theguardian.com/books/2016/apr/15/neoliberalism-the-ideology-at-the-ro 
ot-of-all-our-problems-george-monbiot

Nagourney, A. (2014). Berkeley Officials Outspent but Optimistic in Battle over Soda Tax. New York Times, 7 October 2014, A16.

National Highway Traffic Safety Administration (1996). Costs of Injuries Resulting from Motorcycle Crashes: A Literature Review.

https://www.nhtsa.gov/people/injury/pedbimot/motorcycle/Motorcycle_html.overview

Open.Secrets.Org (2018). American Motorcyclist Association Contributions to Federal Candidates, 2018 Cycle.

https://www.opensecrets.org/pacs/pacgot.php?cycle+2018cmte $=$ C001120238

Open.Secrets.Org (2020). Tobacco.

https://www.opensecrets.org/industries/indus.php?ind+a02.ir

Orentlicher, D. (2013). The FDA's Graphic Tobacco Warnings and the First Amendment. The New England Journal of Medicine, 369, 204-206. https://doi.org/10.1056/NEJMp1304513

Papke, D. R. (2015). Postmodern Decline? The Belief in the Rule of Law as a Tenet of American Ideology. Athens Journal of Law, 1, 221-231.

https://doi.org/10.30958/ajl.1-4-3

Pendall, R. et al. (2011). A Lost Decade: Neighborhood Poverty and the Urban Crisis of the 2000s. Washington DC: Poverty and Race Research Action Council.

Peters E. (2020). Seatbelt Laws, Helmet Laws and Nattering Busybodies. National Motorists Association. https://www.motorists.org/issues/seat-belt-laws-/busybodies/

Peters, C. (1983). The Neoliberal's Manifesto. The Washington Monthly. https://www.unz.org/Pub/Washington-Monthly-1083may-00008

Powell, L. (1971). The Powell Memorandum. Washington \& Lee University School of Law. https://scholarlycommons.law.wlu.edu/powell/memo

Schmitt, R. (2012). Free to Be...Roadkill. Mother Jones. https://www.motherjones.com/politics/2012/06/motorcycle-biker-lobby-helmets-statelaw

Silbey, S. (2006). Ideology. In B. S. Turner (Ed.), Cambridge Dictionary of Sociology (pp. 278-279). Cambridge: Cambridge University Press.

Snowdon, C. (2019). Nanny State Index 2019. Brussels: Epicenter.

Snyder, M. (2012). 18 Examples of the Nanny State Gone Wild. Economic Success Blog. https://www.theeconomicsuccessblog.com/archives/18-examples-of-the-nanny-state-g one-wild

Springer, S., Birch, K., \& MacLeavey, J. (2016). An Introduction to Neoliberalism. In S. Springer, K. Birch, \& J. MacLeavy (Eds.), The Handbook of Neoliberalism (pp. 1-14). London: Routledge.

Thaler, R. H., \& Sunstein, C. (2009). Nudge-Improving Decisions about Health, Wealth, and Happiness. New Haven, CT: Yale University Press.

Thompson, M. (2016). From Trump to Brexit Rhetoric: How Today's Politicians Have Got Away with Words. The Guardian.

https://www.theguardian.com/books/2016/aug/27/trump-to-brexit-rhetoric

Thompson, W. E. (2008). Pseudo-Deviance and the "New Biker" Subculture: Hogs, Blogs, Leathers, and Lattes. Deviant Behavior, 30, 89-114.

https://doi.org/10.1080/01639620802050098

Tobacco Tactics (2016). Countering Arguments against Plain Packaging: The Nanny State Gone Too Far.

https://www.tobaccotactics.org/.../Countering_Industry_Arguments_Against_Plain_Pa 
ckaging

Tribe, L. (1988). American Constitutional Law(3rd ed.). St. Paul, MN: Foundation Press.

U.S. Food \& Drug Administration (2019). FDA Proposes New Required Health Warnings with Color Images.

https://www.fda.gov/news-events/press-announcements/fda-proposes-new-required-h ealth-warnings-with-color-images

Weatherby, D., \& Day, T. (2012). The Butt Stops Here: The Tobacco Control Act's Anti-Smoking Regulations Run Afoul of the First Amendment. Albany Law Review, 76, 121-165.

Williams, R. (1979). Marxism and Literature. Oxford: Oxford University Press.

World Health Organization (2003). WHO Framework on Tobacco Control. Geneva, Switzerland: WHO.

\section{Case Law}

ABATE of Georgia, Inc. (2001). State of Georgia, 137 F. Supp. 2d 1349 (N.D. Ga.).

American Meat Institute (2014). U.S. Department of Agriculture, 760 F.3d 18.

Boreali (1987). Axelrod, 71 N.Y. 2 d 1.

Central Hudson Gas \& Electric Corporation (1980). Public Service Commission, 447 U.S. 557.

Discount Tobacco City \& Lottery, Inc. (2012). U.S., 674 F.2d 509 (6 ${ }^{\text {th }}$ Cir.).

FDA v. Brown \& Williamson (2000). Tobacco Corporation, 529 U.S. 120.

New York State Coalition of Hispanic Chambers of Commerce (2013). New York City Department of Mental Hygiene et al., 2013 WL 1343607.

New York State Coalition of Hispanic Chambers of Commerce (2014). New York City Department of Mental Hygiene et al., 23 N.Y. 2d 681.

Picou (1989). Gillum, 844 F.2d 1519.

Reynolds, R. J. (2012). Tobacco Company et al. v. FDA, 696 F.3d 1205 (D.C. Cir.).

Wooley (1977). Maynard, 430 U.S. 705.

Zauderer (1985). Office of Disciplinary Council of the Supreme Court of Ohio, 471 U.S. 626. 